\title{
The Role Of Micro Financial Institutions On The Growth Of Smes In Kenya:A Case Study Of Micro Financial Institutions In Kisi Town
}

\author{
Kepha Osoro ${ }^{1}$, Dr Willy Muturi ${ }^{2}$ \\ 1 Kepha MomanyiOsoro Jomo Kenyatta University of Agriculture and Technology Kisii CBD Campus P.o Box \\ 268-40200 Kisii \\ 2 Dr Willy MuturiJomo Kenyatta University of Agriculture and Technology
}

\begin{abstract}
The paper was to investigate the role the micro financial instititutions(MFIs)play in assisting small and medium enterprises(SMEs) grow in Kisii Town. The specific objectives were: To establish the role of credit provision on growth of SMEs in Kisii Town, to determine the role of training offered by MFIs in helping the SMEs to grow and role of savings account from MFIs on growth of SMEs in Kisii Town. From the sampling frame a representative sample of 100 respondents were obtained randomly and a survey was conducted on this sample using structured interview schedules. Data from the respondents was analyzed and translated into useful information using the statistical package for social sciences (SPSS). Frequency distributions were used to draw conclusions. The study established that most of the businesses obtained credit from MFIs. The study revealed that savings account offered by micro financials assist the enterpreneurs in developing a culture of saving. The survey established that accessibility of training is positively related to growth of SMEs. The study concludes that provision of credit amd training and a cheap savings account helps the growth of SMEs. The study recommends that the government and MFIs to make credit easly available and affordable to the SMEs for them to grow. The study also recommends for accessible financial training from MFIsto influence growth of SMEs. The research further recommends for affordable saving account for savings to avoid dependence of MFIs for their growth.
\end{abstract}

Key Terms: Growth, Enterprise,Entrepreneur; Small and Medium Enterprises (SMEs), Training,

\section{Introduction}

Introduction

This chapter contains the background to the study,statement of the problem, research objectives, research questions, significance of the study, the scope and the limitations.

\section{Background to the Study}

Credit provision is absolutely crucial to the success of Small and medium enterprises'; it directly impacts on their day-to-day operations, and, in turn, their profitability (Lam \& Burton, 2005). The concept of Micro financing can be traced back to an obscure experiment in Bangladesh 30 years ago. It has since become a worldwide movement as a development activity, as a way of helping poor people out of poverty (Dicher, 2006). Buckley (1997) captures their prominence role in development of economies; he describes them as the newest darling of the donor community. Other authors have described them as the newest silver bullet for alleviating poverty (Karmani, 2007) while Greer (2008), Gupta and Aubuchon (2008) claim that microfinance shines as a proven way to improve the lives of the poor.

In reference to Kenya, the Small scale enterprise market is an important part of the business banking market. Findings of the Strategic Business Advisors Africa Ltd. (SME Banking Sector, 2007) revealed that there are about 2.2 million small and medium enterprises in Kenya of which 23 percent had bank accounts. The definition given by the Central Bureau of statistics, 2004 is that" Small and medium enterprises constitute of semi organized and an unregulated activity largely undertaken by self-employed persons in the open markets, stalls, in undeveloped plots or streets within urban areas and centers. They often pay fees to the municipal or local councils.

A positive relationship has been documented between small and medium enterprises development and economic growth in developed countries (Harris and Gibson, 2006; Monk, 2000; Sauser, 2005; Birch, 1987; Birch, 1981). Since the 1980s, almost all African countries implemented economic and financial reforms to achieve macroeconomic stability and improve economic governance. In many countries these reforms have led to greater macroeconomic stability, improved fiscal and monetary management as well as better, though still unsatisfactory, overall economic performance. 
Small-scale enterprises play an important small and medium enterprises in the Kenyan economy and are accorded high priority in the development policy (GOK, 2007). They offer many advantages including the creation of jobs in both the rural and urban areas, support for larger industries including the agricultural sector and the utilization of local resources. These types of businesses require very little capital to create jobs, rely primarily on family savings and often provide their own skill training at no cost to the government (Maithaet al., 1997).

The focus of the study is on the on the growth of Small and medium enterprises in Kisii Town. In reference to Kenya, the Small enterprise market is an important part of the business banking market.In spite of the sub-sector being a major source of livelihoods for a large majority, especially those living below the poverty line, the government has not managed to implement major policy provisions geared for the development of the sub-sector and according to Maitha, et al. (1997), the support and attention accorded to small and medium enterprises has not been commensurable to their critical importance in national development.

The Economic Strategy for Wealth and Employment Creation (GoK, 2008) points out that the Government is convinced that employment creation is the most effective strategy forhalting the increasing poverty. Whereas a mix of political, economic and social strategies are needed to bring about the required changes, there is a general consensus that development of micro and small and medium enterprises constitutes one of the main pillars in this endeavor as they are expected to serve as the breeding ground or seedbed from which large firms will emerge. For this and other reasons, donor communities, private sector organizations and the government have continually provided financial and technical support to small and medium enterprises. In addition, a number of related efforts and support growth have been directed towards this sector to enable it to create job opportunities, which will improve the overall economy and assist in poverty reduction.

More recently are the Assistance to Small and medium enterprises Program (GOK, 2007),[4] the Kenya policy paper on development of Micro and Small and medium enterprises for Wealth and Employment Creation for Poverty Reduction (GOK, 2005), the Youth Enterprise Development Fund(GOK, 2007) and the Women Development Fund (GOK, 2006). Some of the growth identified includes provision for training, the creation of an enabling environment, improvement of the necessary infrastructure, provision of extension services, establishment of rural business centers for information dissemination and research.

However, a number of these government policies and plans have been termed as mere proclamations and criticized variously for slow implementation. One of the notable criticisms was that of Maitha (1997), who concluded that the suggested frameworks were far too general and un-implementable. Similarly, the 1999 study by International Center for Economic Growth (ICEG), in collaboration with Central Bureau of Statistics (CBS), asserted that a lot still remains to be done on SMEs with regard to training, management and information, among other issues. Thus, policy implementation shortcomings are a major concern, and a clear focus needs to be maintained so that intervention programs can have a meaningful impact on the Small Enterprise's performance.

\section{Statement of the Problem}

The contribution of SMEs to the economic development has not been adequately highlighted. The small and medium enterprises (SMEs) play an important small and medium enterprises in the Kenyan Economy. According to the Economic Survey (2006), the sector contributed over 50 percent of new jobs created in the year 2005. Despite their significance, past statistics indicate that three out of five businesses fail within the first few months of operation (Kenya National Bureau of Statistics, 2007). Approximately $80 \%$ of Kenya enterprises are Small and medium enterprises which are highly attractive to banks, (Ministry of Trade and Industry, 2003). Kisii town though being small in area coverage has over 20 financial institutions, all of which offer credit to the SMEs for gowth. The the purpose of this study will be to determine and identify the role the financial institutions play in the growth of the small enterprisers and how provision of credit,training and savings account influences the growth of Small and medium enterprises.

\section{Objectives}

The general objective of this study was to find out the role of micro financial institutions on the growth of small and medium enterprises in Kisii Town.

\section{Specific objectives}

The specific objectives of this research will include the following:-

i) To determine the effect of credit on the growth of Small and medium enterprises.

ii) To find out the role of training on the growth of Small and medium enterprises

iii) Torole of savings account in assisting of Small and medium enterprises to do savings for future growth. 


\section{Research Questions}

The specific objectives stated above guided the following key study questions:

i) What is the role credit provision in the growth of Small and medium enterprises?

ii) What role do training from financial institutions have on growth Small and medium enterprises?

iii) What is the role os savings account on the growth Small and medium enterprises?

\section{Significance of the Study}

This study is important in a number of ways: First, the study ventured into a field critical to the development of Small Enterprise. In particular, this study focused on the growth and development of entrepreneurs operating Small and medium enterprises, whose small and medium enterprises has been underestimated both at the local and national level, resulting in little effort being directed at developing and exploiting the inherent potential. The findings of this survey can be used to inform financial institutions on suitable products for these businesses, with a special emphasis of improving the entrepreneurs' welfare through their businesses. The study is useful to the government in policy making regarding the financing of the Small and Medium Enterprises through microfinances and other financial institutions. The policy makers will obtain knowledge on the best mechanisms that should be adopted to finance the Small and Medium enterprises. This study is therefore to act as a guide in designing appropriate policies that will guide MFIs in financing the Small and Medium Enterprises. The study is alsosignificant to scholars who can find it useful in providing information on the small and medium enterprises of microcredit financing on financial performance of Small and Medium Enterprises in Kisii Town and in Kenya as a whole. It can also be of significant to researchers as it provides basis upon which further studies can be carried out on broad subject's microcredit financing of Small and Medium Enterprises and it can also provide reference to scholars.

This research will therefore endeavor to fill in the information gap, useful not only to the banking sector but also to the entrepreneurs in their choice of credit from Banks and other financial institutions for their finances. Researchers and policy makers will tap from the information provided for additional knowledge and planning purposes.

Finally, the study is justified on the grounds that the information availed can assist the Kisii County, Kenya government and other stakeholders in policy formulation and in the development of appropriate approaches for future growth, so as to effectively cater for entrepreneurs in Small and medium enterprises sector. It is hoped that this study will add to the available body of knowledge and increase the understanding of how to best empower entrepreneurs in the Small enterprise sector, so that they in turn can contribute more meaningfully to economic development.

\section{Scopeof the study}

This research coveredvarious SMEs within Kisii Town. The study attempted to investigate the role of MFIs in the growth of small and medium enterprisesinKisii Town.

\section{Introduction}

\section{Literature Review}

This chapter reviewed relevant literature on small and medium enterprises establishment, growth and diversification from books, journals and working documents by business developers and banks. The review explored research works and other secondary data relevant to the study to establish sound understanding of what has been done in the area by other researcher in order to identify knowledge gaps. It also provided a basis for an appropriate conceptual framework for the study.

\section{Banking Services}

The Banking industry in Kenya is governed by the Companies Act, the Banking Act, the Central Bank of Kenya Act and the various prudential guidelines issued by the Central Bank of Kenya (CBK). The banking sector was liberalized in 1995 and exchange controls lifted.

The CBK, which falls under the Ministryof Finance docket, is responsible for formulating and implementing monetary policy and fostering the liquidity, solvency and proper functioning of the financial system.

Banking services can be defined as intangible products that are labor- or skill-intensive, and tangible products such as computers and buildings are used mainly to support this provision of labor (Joo-Gim Heaney, Ronald E. Goldsmith, 1999). Earlier studies point to quality of services, personnel, Price, appropriate products as key determinants of bank choice amongst the small and micro enterprises (Zineldin,1996), (Nielsen et al,1998) (Madill et al,2002) (Moran,2003) Sethna,1992). Kisii town has got a number of other financial 
institutions operating and many more continue coming to the town some with other even operating two branches.

\section{SMEs in Kenya}

SME is defined as those enterprises that employ between five (5) to fifty (50) employees. These enterprises are usually owner managed or directly controlled by the owner-community and are mostly family owned. These enterprises normally operate from business and industrial premises that are tax registered.

On the other hand medium enterprises usually employ over 200 employees and capital assets of about 2 million. SMEs are generally small units specialising production for well defined markets with low capital formation. In this paper the focus will be given to enterprises whose turnover is below 15 million. The important role played by the SMEs in Kenya's economy cannot be over emphasised. The SME contribute immensely to the economic development and wealth creation through employment creation estimated at 3.2 million people in 2003, generation of incomes, increasing productivity, facilitating technological transfers and creation of market linkages among other benefits. Despite all these benefits, however, data on the SME sector in Kenya is scarce. An attempt is made through the compilation of National SMES Baseline Survey in 1999 but unfortunately it is lacking on information for medium-sized firms. The increasing role of the SMEs sector is confirmed by the recently completed Kenya 2003 Economic Survey.

In recognition of the important role by the SMEs sector, the Kenya government prepared the Economic Recovery Strategy for Wealth and Employment Creation, 2003-2007 (ERS) which outlines a recovery centred on a rejuvenated private sector. Reviving private sector activity and investment and specifically micro, small, and medium sized enterprise (MSME) development, feature prominently in the Government's strategy for raising incomes and employment. More recently the Government has outlined its economic development policy in the Vision 2030 which aspires to make Kenya a globally competitive and prosperous nation by the year 2030 . In the Vision, the government has committed to the development and creation of at least five SME industrial parks.

The sector is a major source of employment and income and about 48 per cent of SE operators are women. By the end of the year 2008, informal employment was estimated at 7.9 million accounting for 79.8 per cent of total wage employment, and 85.9 per cent of private sector employment. The contribution of SMEs is more than double that of medium and large manufacturing sector that stands at 7\% of the GDP (GOK, 2003a).

Although some studies have been conducted over the years, it was only in the 1990s that nation-wide studies with a focus on baseline surveys started to be implemented in the country. The first national baseline survey of MSEs in Kenya was conducted in October 1993 by Development Alternatives Inc. in collaboration with the Kenya Rural Enterprise Program (K-REP) and the Central Bureau of Statistics (CBS). Other surveys followed in 1995 and in 1999. The 1999 National MSE Baseline Survey found that there were about 1.3 million MSEs countrywide, employing some 2.4 million people (CBS 1999). Findings from these studies underscored the important small and medium enterprises that MSEs play in Kenya's development process, particularly in the context of generating employment and income opportunities for the majority of the poor people throughout the country. The Seventh Development Plan of Kenya (1993 - 1997) stresses the importance of entrepreneurship in Kenya, and concedes that all aspects of human development benefit from entrepreneurship (GOK, 1996).

The Government of Kenya[2] also recognizes the important contribution of the informal sector to the country's industrialization process. The generation of employment leads to the reduction of unemployment problems and is the primary means of strengthening the country's economy (GOK, 1997). If the objective to industrialize by the year 2020 and Vision 2030 is to be achieved, then the Kenya government has the obligation to encourage the micro and small and medium enterprises sector to play a major small and medium enterprises in providing additional jobs. In particular, more effort needs to be directed to developing the largely underestimated and underutilized potential of women entrepreneurs.

Munene (1999),[6] in a study of small scale enterprises in Mombasa summarized such determinants of performance as: management skills, marketing systems, competence of employees and customer care. It is the management's responsibility to formulate the necessary financial controls in the business, so as to have all necessary financial records kept. Decisions of what style and type of marketing to adopt, size of the marketing budget, what and when to advertise, pricing policy, staffing and employee training policy are all management functions in the entrepreneur's docket(Munene, 1999).

\section{Conceptual Frame Work}

Conceptualization of service quality quality consists of five dimensions: reliability, responsiveness, assurance, empathy and tangibles. Rust and Oliver (1994) contend that service quality consists of three dimensions: service product, (technical quality), service delivery, (functional quality), and the service environment. To this construct, pricing and personnel have been found to add to the quality of services offered 
by banks (Zachariah Boulanouar, 2007 \& Madill et al, 2002). It is on the foregoing premise that the conceptual framework (Fig2.1) has been drawn. Storey (1994) identifies some factors which influence business performance among which are; credit and training. The purpose of the research will be to determine how each independent variables (credit provision, training, market information and interest rates) and interactions on the growth of small-scale enterprises in the Municipality. (Dependent variable).

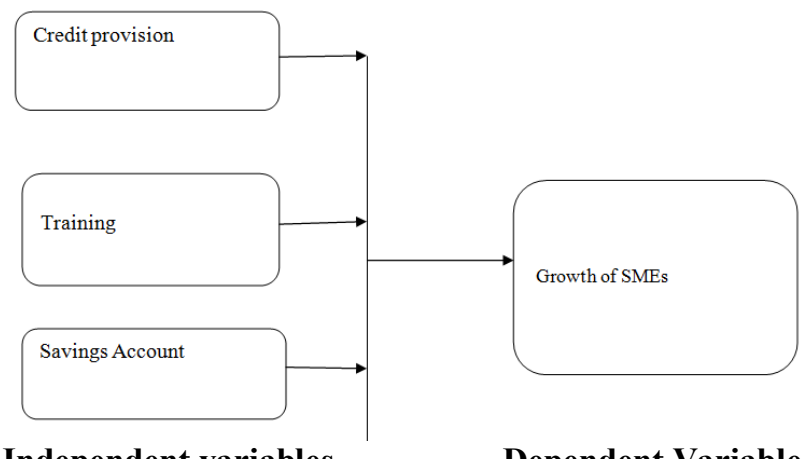

Source:Researcher, (2013)

Figure2.1: Conceptual Framework

\section{Credit provision}

It is now recognized that Small and Medium-sized Enterprises (SMEs) make a significant contribution to the socio-economic and political infrastructure of developed and developing countries as well as the nations in transition from command to market economies (Matlay and Westhead, 2005). Furthermore, a healthy and growing SME sector is perceived to be crucial for sustainable competitive advantage and economic development at local, regional and national levels (Porter, 2006).In a study covering four Southern African countries: Botswana, Malawi, Swaziland and Zimbabwe, access to formal credit helps firms to survive only in Malawi (McPherson, 1995). In Swaziland and Botswana, the firms that borrowed from informal sources had higher chances of closing down than firms that had never borrowed from any source. In Indonesia, when the financial sector was liberalised, many inefficient firms that had been favoured by government and getting credit at low interest rates simply collapsed (Harris et al. 1994). However, good use of credit facilities from the banks have assisted the growth of many firms. Ensuring adequate access to finance so that Small and medium enterprises can grow and achieve their full potential is central to achieving the objectives of the renewed Lisbon partnership for growth and jobs. Kauffmann (2005) suggests that securing suitable financing remains an obstacle for Small and Medium Enterprises, especially for the growth of innovative Small and Medium Enterprises, whose technology and business models are not understood by many more traditional financial institutions and start-up enterprises and very young firms, which lack a track record and collateral against which to raise debt finance (Cousin, 2007).

\section{Training of the entrepreneurs}

Most studies conducted on SMEs, for instance Naituli (2003)[7] agree on the crucial small and medium enterprises of training and management to the successful performance of enterprises. Factors affecting the performance of a business can be divided into two categories: (a) management competence and (b) environmental factors. Management competence encompasses functional knowledge, management skills and managerial behavior. Thus, competencies such as marketing, financial control, training and networking among others, are management functions, although in many studies, the success of the informal sector hinges on the managerial skills of the entrepreneurs who are attracted to the sector due to the relative low investment and service costs required. However the quality of services and goods produced by this sector is much lower than those produced in more formal settings (Kithyo et al., 2004). [5] This can be attributed to the use of low-cost, low quality materials and also lack of relevant or sufficient skills by the various practitioners in the sector. This is evident from the fact that most entrepreneurs in Kenya have come up through apprenticeship, and thus lack sufficient knowledge, skills and technical training that is necessary to undertake businesses in the modern and highly competitive markets.

It is the management's responsibility to formulate the necessary financial controls in the business, so as to have all necessary financial records kept. Decisions of what style and type of marketing to adopt, size of the marketing budget, what and when to advertise, pricing policy, staffing and employee training policy are all management functions in the entrepreneur's docket (Munene, 1999).[6] 
Storey (1994)[8] identifies some factors which influence business performance among which are; ownership, past performance, people/management and location. It is important to note that although the factor of location may be viewed as environmental, it is a management decision where to locate one's business. Kupferberg (1998) who studied humanistic entrepreneurship and entrepreneurial career commitment, concluded that the most important factors of success among humanistic entrepreneurs were: (a) a successful record of previous work history, (b) strong analytical skills acquired in a broad humanistic education, (c) early investment in personal reputation and broad biographical experience outside the narrow field of the profession, (d) early socialization experiences functioning as biographical resources in the discovery of successful business ideas, (e) a training in how to communicate effectively with customers in an increasingly global and knowledge based economy.

\section{Savings Account}

Baumback (1988) states that, a major constraint of small business is its inability to obtain adequate financing, either in an absolute sense or because the cost; in terms of interest rates is often prohibitive. He further argues that the high cost of small business borrowing has put considerable pressure on overall small business marginal profits. The cost of maintaining a savings account influences the business customers in the selection of the microfinance institution for their operations and major influences vary depending on a micro finance institution. However, a very little research (Athanassopoulos and Abroukos, 1999) has been conducted on the bank's product and services importance with small enterprises customers. In this context, an attempt is made to examine the the level of importance attached by small enterprise customers on the various products and accounts offered by the bank.

\section{SMEsgrowth}

The economy of Kenya grew by an average of $4.3 \%$ in the recent past (year 2009); the SMEs contribute significantly to this growth, and offers employment to many people both in the rural and urban areas. The SMEs face tough competition from corporate and large scale businesses. They are depending on micro financing to enhance their growth. Entrepreneurs' performance, indicated by: return on assets, marginal profits and sales growth rate is fundamentally dependent on the entrepreneur. In starting and running a new business, the role of the entrepreneur is vital as the whole process is often heavily dependent on him or her. In part, the know-how in the business is a result of personal contacts and networks the entrepreneur has in relation to other businesses (Niitykangas 1992). Thus, the overall performance of a business can be explained in terms of the characteristics of the entrepreneur. Previous research has suggested that effective management of a relationship can affect client/customer perceptions of quality of service (Ennew and Binks, 1996; Gronroos, 1996; Parasuraman et al., 1988). The satisfaction of the SME consumer will be dependent, at least in part, on the way the bank interacts with the customer and manages the relationship (Ennew and Binks, 1999; Gronroos, 1990; 1996). Such a view is not new; other studies have reported the importance of relationship management in affecting SME perceptions of quality of service.

\section{Research Methodology}

Introduction.

This chapter provides the methods and procedures which werebe followed in conducting the study. These include research design, the target population and size, the research instruments for the data collection, the sampling technique and method to be used for data analysis.

\section{Research Design}

An exploratory research design was be used in conducting study. The nature of research necessitates the use of qualitative and quantities techniques. This is because the study focused on both subjective and objective assessment of Small and medium enterprises growth due to services they get from MFIs.Explanatory designs have been documented (Mugenda\& Mugenda,2003), (Kothari,2002) and advanced as best method for social scientists whose interest is collecting original data for the purpose of describing a population, which is too large to observe directly.

\section{Study Area}

The proposed study on the role of financial institutions on the growth of small scale enterprises wasbe conducted in Kisii Town, Kisii County. The County occupies an area of 126.1 square kilometers and according to the 2009 population census results; it has a total population of 114615 persons. The municipality hosts Kisii town which is a major urban center in the South Nyanza region. Kisii town hosts a variety of businesses including manufacturing, trading (wholesale and retail), service, transportation and agricultural types. 


\section{Target population}

The Population of this study constituted of 100enterpreneursin Kisii Town. The researcher used 10\% to select sample respondents 100 respondents from the entreprepreneurs in the region who formed the sample population size for this study. According to Mugenda and Mugenda (2003), a representative sample is one that is at least $10 \%-20 \%$ of the population.

\section{Sample size and Sampling techniques}

The sampling frame for the planned research was 1000 small and medium enterprises cutting across the main three market locations. The sample size was computed as shown by the formula below:

$$
\begin{gathered}
n=\frac{N C^{2}}{C^{2}+(N-1) e^{2}}=\frac{1000 * 0.5^{2}}{0.5^{2}+(1000-1) * 0.03^{2}}=100 \\
\text { Where } n \text { is the sample size } \\
N \text { is the population } \\
\mathrm{C} \text { is the Coefficient of variation }(0.5) \\
\quad e \text { is the level of precision }(0.03)
\end{gathered}
$$

(Nassiuma, 2000)

From the sampling frame a representative sample of 1000 respondents was obtained. However, stratified random sampling technique used in selecting study zones. The key component behind all probability sampling approaches is randomization (Kombe and Tromp, 2006). In probability sampling; subjects are randomly selected with each unit in the population having an equal chance of being selected. This sampling technique enables the researcher to generalize his findings and make inferences from a sample, thus enabling one to draw conclusions about a population.However, stratified random sampling technique was used in selecting study zones. The key component behind all probability sampling approaches is randomization. In probability sampling; subjects are randomly selected with each unit in the population having an equal chance of being selected. This sampling technique enables the researcher to generalize his findings and make inferences from a sample, thus enabling one to draw conclusions about a population.

The sampling frame comprised 1000 small enterprise entrepreneurs operating in Kisii town. The use of stratified random sampling means that the sample is more likely to be representative and one can hope that each of the strata is represented proportionately within the sample (Saunders et al., 2000). This technique is used to group population into homogeneous subsets that share similar characteristics and ensure equitable representation of the population. It also accounts for the difference in subgroup characteristics.

\section{Data collection instruments and Procedures}

The researcher used primary sources to collect data for this study due to its nearness to truth and ease for control over errors. A structured questionnaire was used to collect the data from the respondents; the questionnaires were administered by the researcher. This enabled the researcher to explore all aspects relating to role of MFIs in enhancing growth of SMEs. Price, (2002) maintains that closed questionnaires controls respondents from giving irrelevant information, (2002).

\section{Data Analysis and Presentation}

Primary data collected was coded and analyzed with the help of the Statistical Package for Social Sciences (SPSS). The results was presented using tables for ease of understanding.

Secondly, the data was coded and keyed in to an Excel Computer based application Programme to analyze the relationship between the independent and dependent variables as fore stated.

The colleceted data was analyzed using descriptive statistics such as frequencies and percentages. Descriptive statistics allowed for the generalization of the data so as to give an account of the characteristics of the population as represented by the sample. Analyzed data was presented in tables. The use of tables was to allow for orderly arrangement of data

\section{Findings And Discussion Introduction}

This chapter presents data analysis and discusses key findings. The main objective of this chapter is the presentation and analysis of the findings on the role of Financial Institutions on growth of Small and medium enterprises in Kenya. Tables have been used to present the findings. The chapter also aims to investigate the sample characteristics of the 100 Small businesses who were interviewed in this survey. This chapter investigated sample characteristics, provide descriptive statistics on the responses for each variable and the relationship between different variables. 
Start-up Capital and Loan information

Borrowing from micro financial institutions banks was $50 \%$. Other sources of startup capital were personal savings in the account $30 \%$ and friends $(20 \%)$.

Table 4.6: Sources for start-up capital $(N=100)$

\begin{tabular}{|ccc|}
\hline Main source of start-up capital & Frequency & Percent \\
\hline Borrowed from MFIs & 50 & 50 \\
\hline Personal savings & 30 & 30 \\
\hline Friends & 20 & 20 \\
\hline
\end{tabular}

\section{Provision of credit and growth of SMEs}

The survey sought to find out the contribution of credit for growth and performance of small and medium enterprises. It was necessary to understand the contribution of the credit for the enterpreneurs in the town. The table below shows the contribution of the credit to the growth of small and medium enterprises in Kisii Town.

Contributions of the Creidt to growth of SMEson sales volume.

\begin{tabular}{|lcc|}
\hline Credit contribution to growth & $\mathrm{N}=100$ & $\%$ \\
\hline No change in sale volume & 16 & 16 \\
\hline Increase in sales volume & 84 & 84 \\
\hline
\end{tabular}

From the table above, $16 \%$ of the respondents had no change in the sales after they got the credit from the banks. $84 \%$ of the respondents had increase in sales growth.

Contributions of the Creidt to growth of SMEsverses profit margins.

\begin{tabular}{|lcc|}
\hline Credit contribution to growth & $\mathrm{N}=100$ & $\%$ \\
\hline No change in profit margins & 15 & 15 \\
\hline Increase in profit margins & 85 & 85 \\
\hline
\end{tabular}

From the table above, $15 \%$ of the respondents had no change in the profit margins before the provision of credit and after they got the credit from the banks. However, $85 \%$ of the respondents had increase in profit margins after the secured a credit facility from the MFIs compared when they had not taken the loan.

\section{Training verses growth of SMEson sales volume}

From the respondent on availability of training from financial institutions, the study found that $5 \%$ of the respondent had no change in sales volume after training from financial institutions while $95 \%$ of the respondent had an increase of sales volume after trainings. This indicates the necessisty of financial training on the growth of SMEs.

Training for Entrepreneurs

\begin{tabular}{|lcc|}
\hline Training Availability & $\mathrm{N}=100$ & $\%$ \\
\hline No change in sale volume & 5 & 5 \\
\hline Increase in sales volume & 95 & 95 \\
\hline
\end{tabular}

Contributions of the Training of SMEsverses profit margins.

\begin{tabular}{|lcc|}
\hline Credit contribution to growth & $\mathrm{N}=100$ & $\%$ \\
\hline No change in profit margins & 10 & 10 \\
\hline Increase in profit margins & 90 & 90 \\
\hline
\end{tabular}

From the table above, $10 \%$ of the respondents had no change in the profit margins before the training from the financial institutions and after the training from the banks. However, $90 \%$ of the respondents had increase in profit margins after training by MFIs compared when they had not been trained.

\section{Savings Account}

Contributions of the Training of SMEsverses profit margins.

\begin{tabular}{|lcc|}
\hline Credit contribution to growth & $\mathrm{N}=100$ & $\%$ \\
\hline No change in profit margins & 10 & 10 \\
\hline Increase in profit margins & 90 & 90 \\
\hline
\end{tabular}


From the table above, $10 \%$ of the respondents had no change in the profit margins before the training from the financial institutions and after the training from the banks. However, $90 \%$ of the respondents had increase in profit margins after training by MFIs compared when they had not been trained.

\section{Contribution of a savings Accountto profit margins}

\begin{tabular}{|lcc|}
\hline Profit margin and savings account & $\mathrm{n}=100$ & $\%$ \\
\hline No increase of profit margins & 30 & 10 \\
\hline An increasein profit margin & 70 & 70 \\
\hline
\end{tabular}

From the table above, $30 \%$ of the respondents had no change in the profit margins before and after they opened a savings account with the MFIs. $70 \%$ of the respondents had increase in profit margins after saving their profits with the MFIs.

\section{Changes in sales volume afersaving in Banks}

Only $13 \%$ had not experienced the increase of the sales volume after the opening and operating a savings account with the MFIs while $87 \%$ had an increase of sales volume after thesavings with financial institutions.

Sales volume after use of savings account

\begin{tabular}{|lcc|}
\hline & $\mathrm{N}=90$ & $\%$ \\
\hline No increase in sales & 13 & 13 \\
\hline Iincrease in sales & 87 & 87 \\
\hline
\end{tabular}

\section{Growth of SMEs}

$90 \%$ of the entrepreneurs indicated their businesses has grown after the loans,training and opening of a savings account with the MFIs compared with $10 \%$ who indiocated otherwise.

\section{Gwoth of SMEs $(N=100)$}

\begin{tabular}{|lcc|}
\hline How do you rate your business & Frequency & Percentage \\
\hline Successful & 90 & 90 \\
\hline Un-successful & 10 & 10 \\
\hline TOTAL & $\mathbf{1 0 0}$ & $\mathbf{1 0 0}$ \\
\hline
\end{tabular}

\section{The various contributions to the growth of businesses}

The study further revealed that $50 \%$ of the respondent agreed that credit was the most important for their growth as a business, while $30 \%$ of the respondents were of the opnion that training was the most important for the growth of their business and operation while $20 \%$ are for the savings account as the most important aspect that helps them in their business growth.

\section{Reasons for growth}

\begin{tabular}{|lcc|}
\hline Most importanf in business growth & $\mathrm{n}=100$ & $\%$ \\
\hline Credit & 50 & 50 \\
\hline Trainning & 30 & 30 \\
\hline Savings Account & 20 & 20 \\
\hline
\end{tabular}

\section{Introduction}

\section{Summary, Conclusion Andrecommendations}

This chapter discusses the findings and makes conclusions and recommendations from the data collected and analyzed. The study sought responses basing the questions on the objectives of the study. The researcher intended to analyze and find out the small and medium enterprises of financial institutions intervention on growth of Small and medium enterprises in Kenya. A Survey of transport industry in Kisii Town. 90 respondents were interviewed of whom $86 \%$ were the sole decision makers and the rest had influence or little say in the decision making. Therefore, the data collected was from entrepreneurs who knew the business operations and history very well. The specific objectives were: To establish the small and medium enterprises of credit provision on growth of Small and medium enterprises in Kisii Town, to determine the adequacy of training offered by financial institutions in helping the small and medium enterprises to grow, to determine the small and medium enterprises of market information on growth of small and medium enterprises in Kisii Town. From an enumerated population of 1000 entrepreneurs, a sample of 90 was selected randomly and a survey was 
conducted on this sample using both structured and un-structured questionnaire. Data from the respondents was analyzed and translated into useful information using the Statistical Package for Social Sciences (SPSS).

The study investigated four main area that affect the growth of small and medium enterprises that is:accessibility to loans,availability of training,accessibility to market information and intrest rates on the loans. From the findings, $71 \%$ of the entrepreneurs operated as sole proprietors and were therefore the main decision makers in their business. Personal savings was the main source of business start-up capital at $(46 \%)$ while 45 $(50 \%)$ had accessed credit from the banks for their growth.

\section{Summary of Findings}

The findings revealed that most of the respondents in this study reported that their business had expanded and their house hold income had increased significantly as a result of having taken microfinance loans. The study revealed that $6 \%$ of the respondents had no change in the sales after they got the credit from the banks. $42 \%$ of the respondents had a slight positive growth in sales volume of their sales contributed by the credit accessed from the financial institutions. $38 \%$ of the respondents had a moderate positive growth in sales volume while $14 \%$ had a high sales volume after the access to credit.

On availability of training from financial institutions, the study found that $42 \%$ of the respondent had moderate increase of sales volume after training from financial institutions, $28 \%$ of the respondent had high increase of sales volume after trainings, $14 \%$ had an increase of sales volume after training and $6 \%$ of the respondent said there was no change of sales volume after training from the financial institutions.

$44 \%$ of those participated in the study responded that the availability of the information from financial institutions had increased their profit margins slightly while $32 \%$ were in agreement that the availability of market information from financial institutions has moderately increased their profit margins. Only $8 \%$ were not in agreement that there is any increase of profit margins after the use of the markert information and $16 \%$ said that such information is had enebled their businesses to experience a very high profit margins. The table 4.8 below shows the availability of market information from financial institutions and its small and medium enterprises on the profit margins.

The study revealed that on the growth based on the number of employees, employees were found to be an indicator of growth of the entrepreneur. The respondents were asked to share their expectations; if they had added any employee from the time they had market information. $4 \%$ said that they they have added one employee, $28 \%$ had added 2 more employees, $30 \%$ had added 3 more employees while $28 \%$ had added 4 or more employees into their business after they had applied market information they got from the financial institutions.

\section{Conclusion}

The study concludes that accessibility to credit affects financial performance of Smaill enterprises positively. The easier it is to access credit, the higher the financial performance of the Small and medium enterprises. However, access to credit is not that easier from the financial institutions considering the many requirements one has to meet before the credit is approved to the entrepreneur for use in the business.

The study also concludes that availability of credit positively affects financial performance of small and medium businesses. Most respondents said that once loans were applied for, it took the expected time for them to receive the money and this affected their business postively. This is an indication that as credit becomes more available, the financial performance of business becomes better and hence a chance for business growth.

The study further concludes that the interest paid on micro credit facilities were affordable. The interest rates would however affect financial performance of the businesses negatively. As the interest rate increases, the credit facility becomes more expensive and eats into the business profits.

Training was found to be playing a crucial small and medium enterprises in growth of small and medium enterprises, especially in assisting the businesses to repay back their loans in order to get more credit in future. The research further found out that theassessibilty to market information and its availability to the enterpreneurs also affects the transporters in a positive way in their performance of the businesses. The study further revealed that $41 \%$ of the respondent agreed that credit was the most important for their growth as a business, while $33 \%$ of the respondents were of the opnion that training was the most important for the growth of their business and operation while $26 \%$ are for the market information as the most important aspect that helps them in their business growth.

\section{Recommendations}

The study recommends that the MFIs should make credit accessible and available to enhance growth and development of Small and medium enterprises through increased profitability and sales volume 
The study also recommends for mechanisms of training where all SMEs should be trained before advanced with loans and after to enhance growth and reduce rates of default. The study recommends further on cheaper and easly accessible savings account facilitated with technology for ease accessibility and technologicalyy friendly services line mobile banking.

\section{References}

[1] Bosire, J. (2000). Measuring business skills cognition: The case of informal sectorentrepreneurs in Kenya.Eastern Africa Social Science Research Review - Volume 19, Number 2, June 2003, pp. 1-21.

[1] Bosire, J. \& M Etyang (2003).The effect of education on business skills cognition: the case of indigenous microscale enterprise owners in Kenya. Journal of Vocational Education \& Training, Volume 55, Issue 1 March 2003, pages 5-20.

[2] Edgar Online Inc. (2003). California Pizza Kitchen operations:- Report on Management operations. Califonia Finance Magazine, pp.6-9.

[3] Elizabeth, OrchardsonMazrui, (2004). The impact of cultural perspectives on gender issues.In Eunice Smith (Ed.).Gender Inequalities in Kenya, (pp. 145-160); UNESCO.

[4] Government of Kenya (2007).Assistance to micro and small and medium enterprises Programme: A Ministry of Trade Initiative. Nairobi: Government Printer.

[5] Kithyo, I., Kipkurui, L. Okemwa\& P. Korir, J. (2004). Modernization in automotive technology and performance of informal sector mechanics.:CIGR Journal of Scientific Research and Development. Invited Overview Paper, VI.; MoiUniversity.

[6] Munene, C. M. (1999). Strategies enhancing small enterprise tourists totels competitiveness.Case study of Mombasa Kenya.Unpublished MSc Thesis, Jomo Kenyatta University of Agriculture and Technology.

[7] Naituli, G.,Wegulo, Francis N. \&Kaimenyi, B. (2006). Entrepreneurial Human Capital and Growth of Micro and Small Scale Women enterprises in Rural Kenya.

[8] Storey, D. J.(1994). Entrepreneurship and the new firm.London: Croom Helm. 